\title{
EXPERIMENTAL INVESTIGATION OF THE MAXIMUM PUNCHING RESISTANCE OF SLAB-COLUMN CONNECTIONS
}

\author{
Jaroslav HALVONÍK', Lucia MAJTANOVÁ²
}

\section{Abstract}

Flat slabs represent a structural system with a typical concentration of shear forces near the vicinity of its local supports. A possible failure from punching is a dangerous phenomenon due to the brittleness and possible progressive collapse of a whole structure. An improvement in the structural behaviour of a slab-column connection provides transverse reinforcement. The amount of this reinforcement and thus its contribution to the resistance against punching has a limit, which is represented by the maximum punching capacity. This capacity can be assessed using the kmax factor or by direct verification of the strut capacity. The article deals with the results of a test campaign carried out on flat slab specimens with their transverse reinforcements designed in such a way that the crushing of the struts is the governing mode of any failure. The test results obtained allowed for an evaluation of the kmax factors and provide an answer as to whether it is possible to cover failures due to the crushing of struts by this factor.

\section{Address}

1 Slovak University of Technology, Faculty of Civil Engineering, Dept. of Concrete Structures and Bridges, Bratislava, Slovakia

* Corresponding author: jaroslav.halvonik@stuba.sk

\section{Key words}

- Punching,

- Flat slab,

- Shear resistance,

- Concrete strut,

- Shear crack.

\section{INTRODUCTION}

Punching is one of the most dangerous forms of the structural failure of reinforced concrete slabs due to their brittleness, particularly when it occurs prior to the yielding of a bending reinforcement. The application of a transverse reinforcement allows for a significant increase in the resistance to punching shear and ductility in comparison with flat slabs without any shear reinforcement. However, many experiments have shown some limits which even a very heavily reinforced flat slab with a shear reinforcement is not able to overcome. This means that there are some limits which have to be imposed on the amount of shear reinforcement taken for the verification of the punching capacity. This limit is represented by the maximum punching capacity and is normally given by the resistance of the concrete struts at a column's periphery. The capacity of the struts can be expressed by formula (1), which has been introduced in the current EC2 (2004) model for punching. This limit is usually decisive for thick slabs or slabs with a large amount of bending reinforcement and with a small loaded area surrounded by a column periphery, Einpaul, Bujnak, Ruiz, Muttoni (2016).

$$
V_{\mathrm{Rd}, \max }=0.5 * v f_{\mathrm{cd}} u_{0} d
$$

where $f_{\mathrm{ck}}$ is the characteristic cylinder strength of the concrete

$$
\begin{aligned}
& f_{\text {cd }} \text { - design strength of concrete } f_{\text {cd }}=f_{\text {ck }} / \gamma_{\mathrm{C}} \\
& u_{0} \text { - the length of the column periphery } \\
& d \text { - the effective depth of the slab } \\
& v \text {-reduction factor } v=0.6 *\left(1-f_{\mathrm{ck}} / 250\right) \text { in }[\mathrm{MPa}]
\end{aligned}
$$

Note: The value of 0.5 in (1) should be replaced by 0.4 if the $\beta$ factor is evaluated for a control perimeter different from $u_{0}$. Factor $\beta$ takes into account the effect of unbalanced bending moments.

Some standards and models for punching control the maximum punching capacity indirectly by the $k_{\max }$ factor. This factor expresses how many times the punching resistance with a shear reinforcement can 
Tab. 1 An overview of the $k_{\max }$ factors

\begin{tabular}{|c|c|c|c|c|}
\hline Model & $\begin{array}{l}\text { Position of the basic control } \\
\text { perimeter } u_{1}, b_{0}\end{array}$ & Notes & Value of the $k_{\max }, k_{\mathrm{sys}}, \alpha_{\text {max }}, \eta_{\text {sys }}$ & Type of shear reinforcement \\
\hline EC2 (2004) & $2 d$ & recommended & 1.5 & all \\
\hline EC2 (2004) & $2 d$ & Germany & 1.4 & all \\
\hline EC2 (2004) & $2 d$ & United Kingdom & 2.0 & all \\
\hline EC2 (2004) & $2 d$ & Sweden & 1.6 & all \\
\hline \multirow{2}{*}{ EC2 (2004) } & \multirow{2}{*}{$2 d$} & \multirow{2}{*}{ Austria } & 1.9 & studs \\
\hline & & & $1.4-1.6^{1}$ & stirrups, bent-ups \\
\hline \multirow{2}{*}{ EC2 (2004) } & \multirow{2}{*}{$2 d$} & \multirow{2}{*}{ Slovakia } & 1.9 & studs \\
\hline & & & $1.4-1.7^{1}$ & stirrups, bent-ups \\
\hline ETA-13/0151 & $2 d$ & - & 1.96 & studs \\
\hline \multirow{2}{*}{ MC 2010} & \multirow{2}{*}{$0.5 d_{\mathrm{v}}$} & \multirow{2}{*}{-} & 2.4 & stirrups, bent-ups \\
\hline & & & 2.8 & studs \\
\hline \multirow{2}{*}{ CF CSCT } & \multirow{2}{*}{$0.5 d_{\mathrm{v}}$} & - & 1.5 & stirrups, bent-ups \\
\hline & & - & 1.8 & studs \\
\hline \multirow{2}{*}{ ACI $318-14$} & \multirow{2}{*}{$0.5 d$} & - & 1.52 & stirrups, bent-ups \\
\hline & & - & 2.0 & studs \\
\hline
\end{tabular}

be higher than the resistance of the same slab without any shear reinforcement. This limit was also supplemented in Eurocode 2. Test results have shown that the value of the factor depends on the type of shear reinforcement, e.g., studs, stirrups, cages, bent-down bars, etc. The most important property is the anchoring ability of the shear reinforcement. An overview of the $k_{\max }$ factor values can be found in Table 1 .

The values of $k_{\max }^{\max }$ in Table 1 are very diverse and depend on the country, design model, and type of shear reinforcement, e.g., in the case of the EC2 (2004) model, we have several values ranging from the maximum value of 2.0 in the UK to the minimum 1.4 in Germany. Therefore, we can ask if we are able to cover the phenomenon of the crushing struts by the $k_{\max }$ factor. Is it possible to avoid control of the strut capacity from the design for punching? In order to find at least a partial answer to this question, an experimental campaign was carried out in the Central Laboratories of the Faculty of Civil Engineering, STU, in Bratislava.
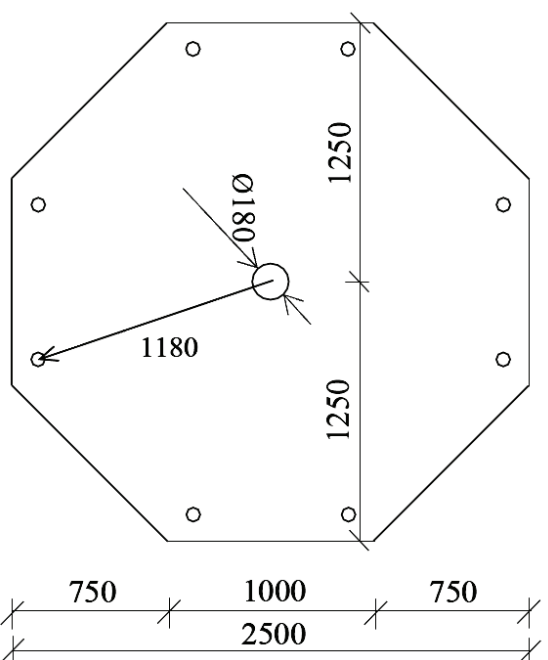

Fig. 1 Test specimen - view of plan

\section{DESCRIPTION OF THE EXPERIMENTAL PROGRAM}

The experimental specimens were octagonally-shaped flat slab fragments with a thickness of $250 \mathrm{~mm}$, see Fig.1. The specimens were supported by columns with a small diameter of $180 \mathrm{~mm}$ in order to minimize the length of the column periphery, ratio $u_{0} / d=2.83$. The slabs were reinforced by a $\phi 20 / 100 \mathrm{~mm}$ bending reinforcement made from $\mathrm{B} 500 \mathrm{~B}$ steel. The average reinforcement ratio was $1.57 \%$, and the average effective depth was $200 \mathrm{~mm}$.

Two specimens (S1-1 and S2-1) were reinforced by a transverse reinforcement consisting of double-headed Peikko PSB studs with a diameter of $10 \mathrm{~mm}$ from B500B steel, see Fig. 2. The number of studs in one perimeter was 15 and 16. The two specimens (S1-2 and S2-2) were without any shear reinforcement. Specimens S1-1 and

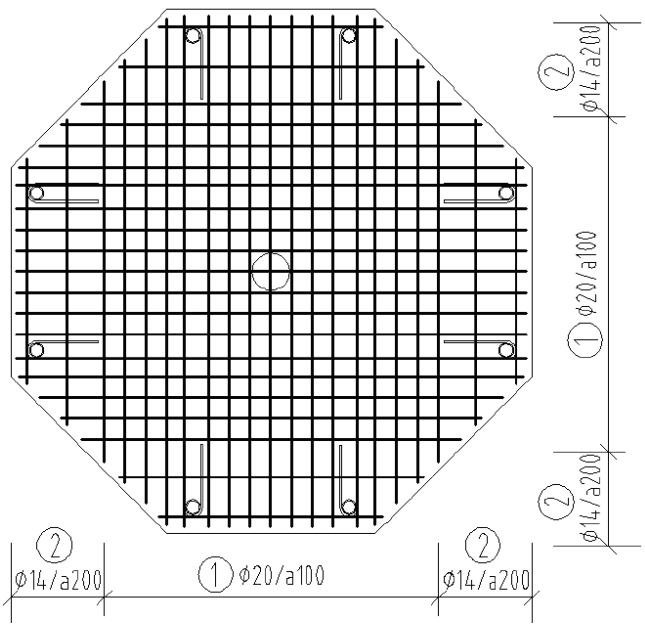


Tab. 2 Parameters of the test specimens and test results

\begin{tabular}{|c|c|c|c|c|c|c|c|c|c|}
\hline Slab & $d[\mathrm{~mm}]$ & $\rho[\%]$ & $a_{\mathrm{v}} / d$ & $f_{\mathrm{cm}}[\mathrm{MPa}]$ & $f_{\mathrm{ym}}[\mathrm{MPa}]$ & $u_{0} / d$ & studs & $n_{\mathrm{st}}$ & $V_{\mathrm{R}, \text { test }}[\mathrm{kN}]$ \\
\hline S1-1 & \multirow{4}{*}{200} & \multirow{4}{*}{1.57} & \multirow{4}{*}{5.9} & 38.2 & \multirow{2}{*}{577} & \multirow{4}{*}{2.827} & Yes & 15 & 1520 \\
\hline S1-2 & & & & 41.0 & & & No & - & 903 \\
\hline S2-1 & & & & 28.1 & \multirow{2}{*}{538} & & Yes & 16 & 1250 \\
\hline S2-2 & & & & 28.1 & & & No & - & 690 \\
\hline
\end{tabular}
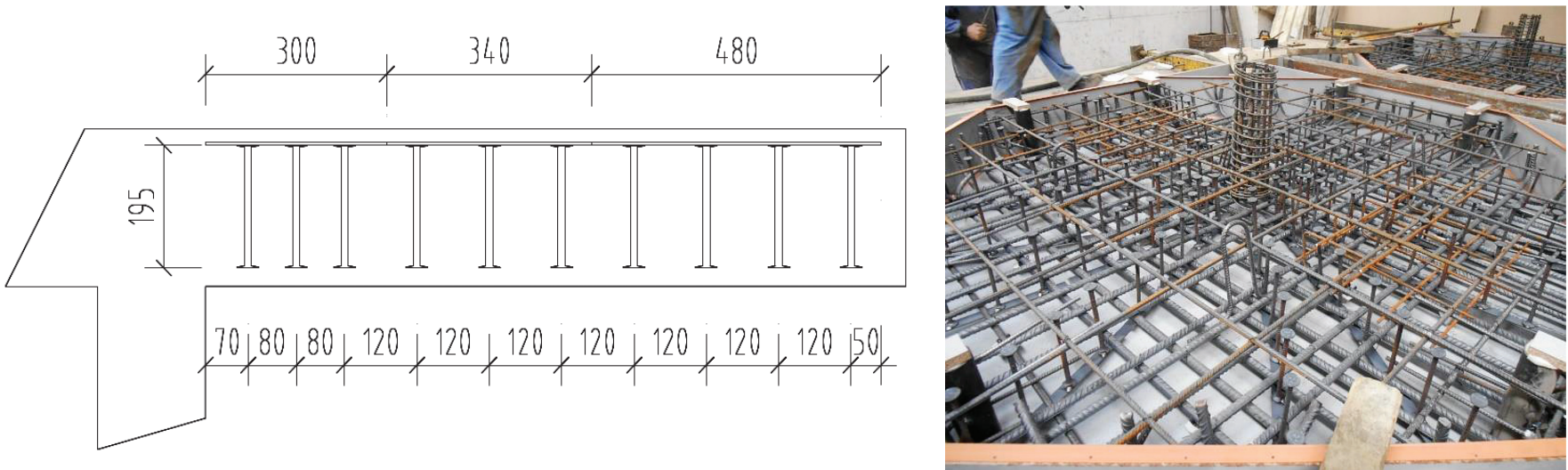

Fig. 2 Peikko PSB studs - arrangement of the shear reinforcement

S1-2 were cast at different times using the same C35/45 concrete. Specimens S2-1 and S2-2 were cast together from C20/25 concrete, see Table 2. The maximum aggregate size was $16 \mathrm{~mm}$.

\subsection{Test set-up}

The test specimens were put on a hydraulic jack and anchored to the floor by 8 high-strength rods with a diameter of $50 \mathrm{~mm}$ through the steel frame, see Fig. 3. The slabs were loaded under axis-symmetric conditions. The load was measured by a force cell with a capacity of $2000 \mathrm{kN}$. The force cell was inserted between the jack plate and the tip of the column. Any strains were measured by 1-LY41-50/120 HBM strain gauges on the bottom (compression) and used the attached digital-indicator gauge on the top surface (tension). Any displacements were measured by digital displacement gauges and the photogrammetry method.
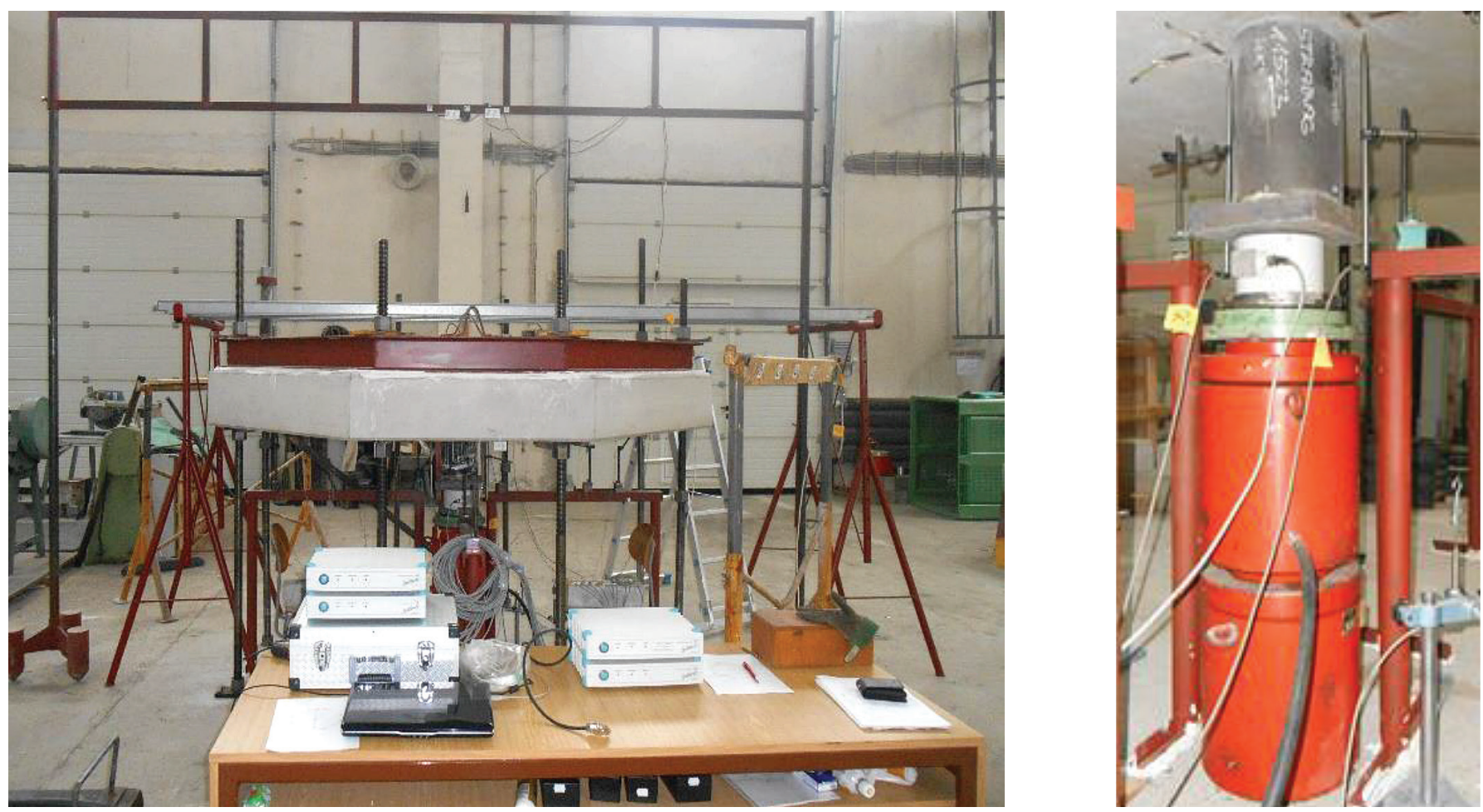

Fig. 3 The test set-up and details of the hydraulic jack arrangement with force cell 


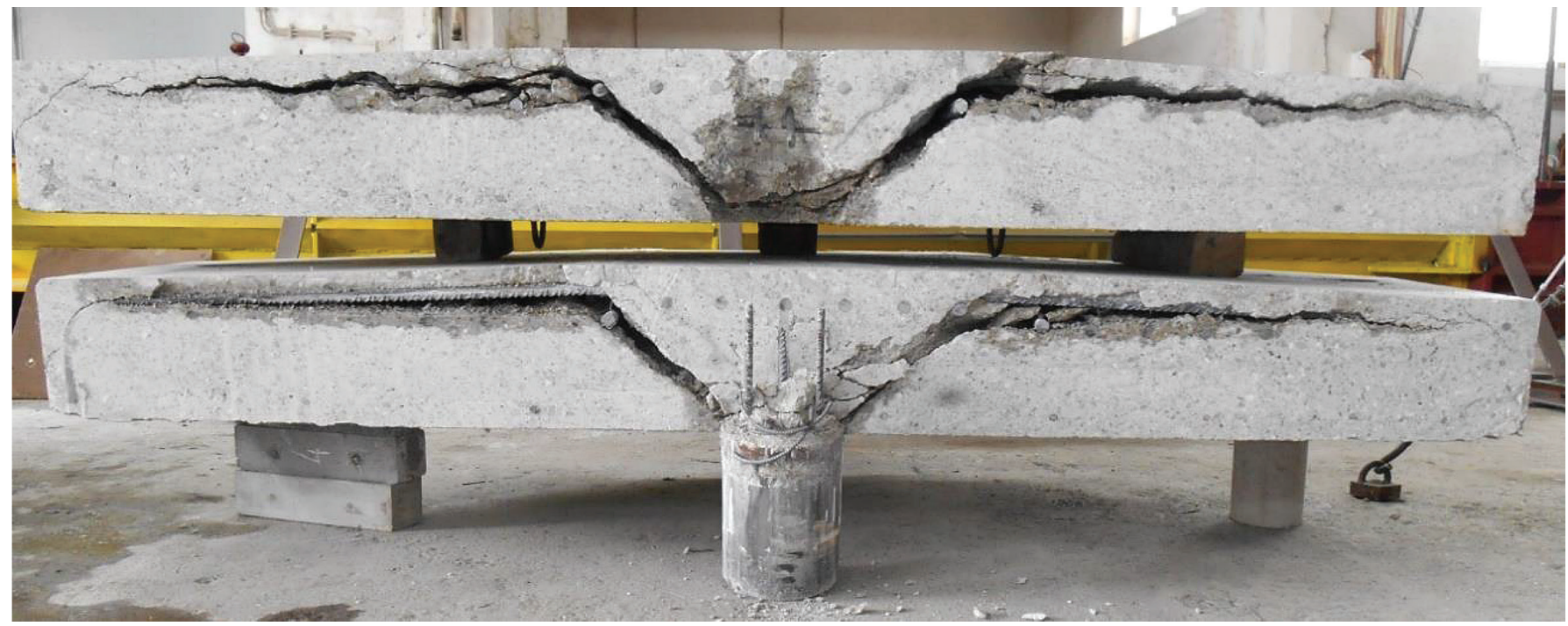

Fig. 4 Saw-cut section - specimen S1-2 without any transverse reinforcement

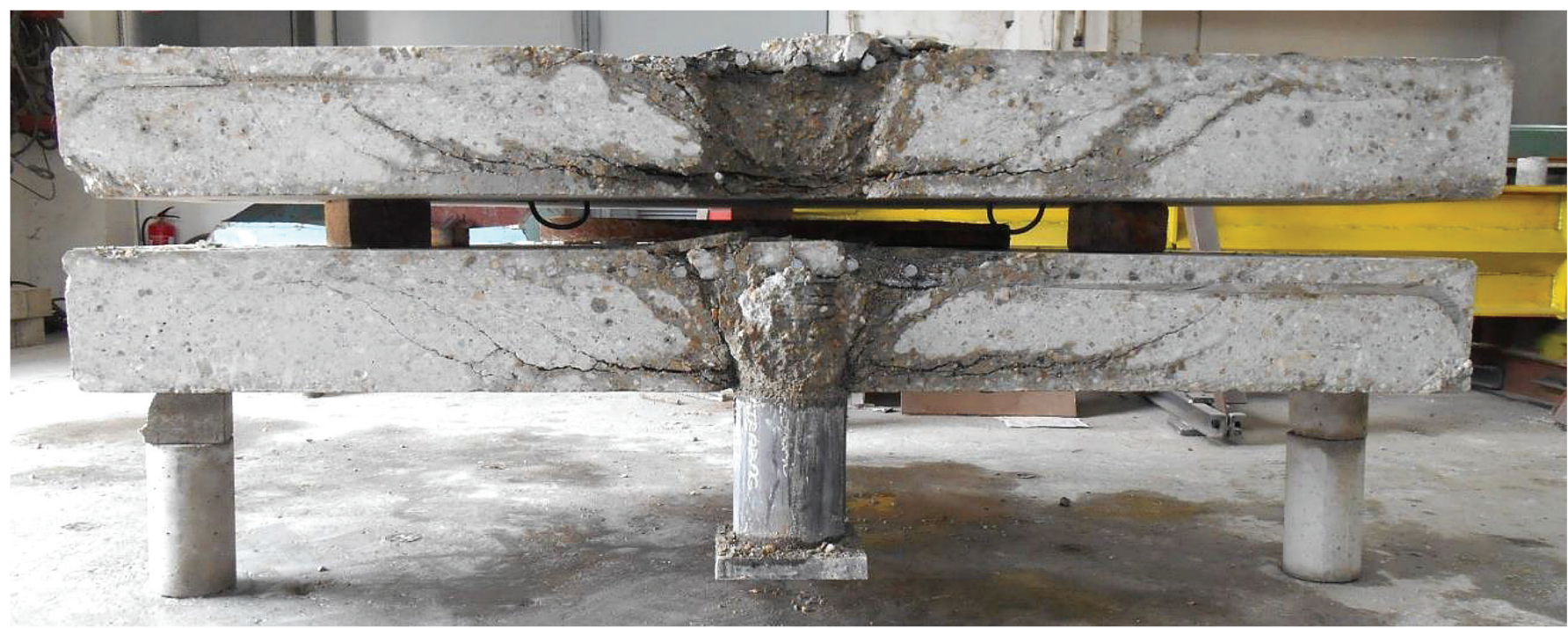

Fig. 5 Saw-cut section - specimen S2-1 with a transverse reinforcement

\subsection{Results}

The slabs without any shear reinforcement failed in a very brittle mode and with a typical cone. A critical shear crack was inclined under an approximate angle of $25^{\circ}$ for specimen S1-2 (Fig. 4); in the case of slab S2-2 (a lower strength of concrete), the inclination of the critical shear crack was even flatter. The specimens with a shear reinforcement failed in a different way. When a column started to penetrate the slab, the crushed concrete was observed to be dropping at the column's periphery. The damaged area was significantly smaller in comparison with the specimens without any shear reinforcement. The critical crack was very steep, and the punching cone was much smaller than in the cases of the specimens without any shear reinforcement, see Fig. 5. It is possible to say that the governing mode of failure was the crushing of the concrete struts at a column's periphery.

A displacement - force diagram is shown in Fig. 6. The diagram shows significant improvement in the ductility of the specimens that were reinforced by transverse reinforcements. The displacement measured between the center of the specimen and the anchored rods was 2.7 times higher in the case of slab S1-1 and 2.5 times in the case of

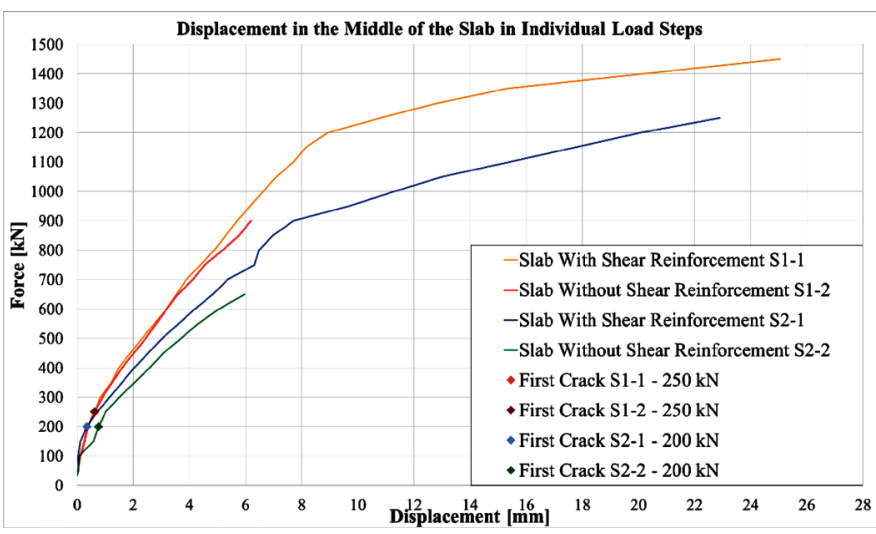

Fig. 6 Force - displacement diagram

slab S1-2 compared with the slabs without any shear reinforcement. The slabs without any shear reinforcement had the same deformation capacity; in spite of different punching capacities, both failed when the displacement reached a little bit more than $6 \mathrm{~mm}$. 


\section{EVALUATION OF THE EXPERIMENTAL RESULTS}

\subsection{Models for the assessment of punching resistance}

Four models for an assessment of punching resistance were used to evaluate the experiments. Two empirical models, the current Eurocode 2 and ETA 13/0151, and two models based on the Critical Shear Crack Theory (CSCT), Model Code 2010 model with a Level of Approximation III (LoAIII) and a closed-form CSCT model, were used. The EC2 empirical model (2004) was developed based on the research work of Zsutty (1968) and its modification, i.e., ETA 13/0151, by Muttoni and Bujnak (2013). The CSCT models were developed by Muttoni and Schwartz (1991), Muttoni and Ruiz (2008), Ruiz and Muttoni (2009) and (2017).

\section{Eurocode 2 model - EC2 (2004)}

The maximum punching capacity is determined in two ways: first, by control of the strut capacity, see formula (1), and for the second, by the $k_{\max }$ factor, see Table 1 , which is applied with a punching resistance without any shear reinforcement $V_{\mathrm{Rd}, \mathrm{c}}$.

$$
V_{\mathrm{Rd}, \mathrm{c}}=\frac{C_{\mathrm{Rk}, \mathrm{c}}}{\gamma_{\mathrm{C}}} k\left(100 * \rho f_{\mathrm{ck}}\right)^{1 / 3} u_{1} d
$$

where:

$C_{\mathrm{Rk}, \mathrm{c}}$ is an empirical factor $C_{\mathrm{Rk}, \mathrm{c}}=0.18 \mathrm{MPa}$

$\rho$-reinforcement ratio, $\rho=\left(\rho_{\mathrm{x}} \rho_{\mathrm{y}}\right)^{0.5}$

$\rho_{\mathrm{x}(\mathrm{y})}$ - reinforcement ratios of the main reinforcement in orthogonal directions $\rho_{\mathrm{x}(\mathrm{y})}=A_{\mathrm{sx}(\mathrm{y})} /\left(d_{\mathrm{x}(\mathrm{y})} b\right)$

$d$-effective depth, an average value of the effective depths in two orthogonal directions $d_{\mathrm{x}}$ and $d_{\mathrm{y}}$

$k$ - factor which takes into account the effect of the size of $k=1+(200[\mathrm{~mm}] / d)^{0.5}$

$\gamma_{\mathrm{C}}-$ partial safety factor, $\gamma_{\mathrm{C}}=1.5$, for evaluation $\gamma_{\mathrm{C}}=1.0$

$u_{1}$ - basic control perimeter measured at distance $2 d$ from the face of a column

\section{ETA 13/0151 model}

The model introduced in the European Technical Approval ETA 13/0151 is based on EC2 (2004), and formula (2) is applicable here. The maximum punching capacity is only determined by the $k_{\max }$ factor The recommended value, i.e., 1.96, for double-headed studs is very high. In order to include a possible failure due to the crushing of the concrete struts, the empirical factor $C_{\mathrm{Rk}, \mathrm{c}}$ has been modified in such a way that it also depends on the length of the column periphery $u_{0}$.

if $\quad \frac{u_{0}}{d} \leq 4.0 \quad C_{\mathrm{Rk}, \mathrm{c}}=\frac{0.18}{\gamma_{\mathrm{C}}} *\left(0.1 * \frac{u_{0}}{d}+0.6\right) \geq \frac{0.15}{\gamma_{\mathrm{C}}}$

\section{Model Code 2010 LoAIII}

The maximum punching capacity is determined by the $k_{\text {sys }}$ factor, see Table 1, which is applied with a punching resistance without any shear reinforcement $V_{\text {Rd,c }}$. The resistance $V_{\text {Rd,c }}$ is not a constant value and is influenced by rotation $\psi$ of a flat slab at the slab-column connection. The relation between $\psi$ and $V_{\mathrm{Rdcc}}$ expresses the failure criterion $k_{w}$, see formula (6). The rotation of the slab at a column was assessed by formula (8) with the average bending moments per unit length calculated by $m_{\mathrm{Ed}}=V_{\mathrm{R}, \mathrm{test}} / 8$.

$$
V_{\mathrm{Rd}, \text { max }}=k_{\mathrm{sys}} V_{\mathrm{Rd}, \mathrm{c}} \leq \frac{\sqrt{f_{\mathrm{ck}}}}{\gamma_{\mathrm{C}}} b_{0} d_{\mathrm{v}}
$$

$$
\begin{gathered}
V_{\mathrm{Rd}, \mathrm{c}}=k_{\psi} \frac{\sqrt{f_{\mathrm{ck}}}}{\gamma_{\mathrm{C}}} b_{0} d_{\mathrm{v}} \\
k_{\psi}=\frac{1}{1.5+0.9 * k_{\mathrm{dg}} \psi d} \\
\psi=1.2 * \frac{r_{\mathrm{s}}}{d} \frac{f_{\mathrm{yd}}}{E_{\mathrm{s}}}\left(\frac{m_{\mathrm{Ed}}}{\mathrm{m}_{\mathrm{Rd}}}\right)^{1,5}
\end{gathered}
$$

where:

$d_{v}$ - is the effective depth of the slab for shear, usually $d=d$

$b_{0}^{v}$ - length of the control perimeter at a distance of $d_{\mathrm{v}} / 2$ from the face of a column

$k_{\mathrm{dg}}$ - factor depending on the maximum aggregate size $d_{\mathrm{g}}[\mathrm{mm}]$, $k_{\mathrm{dg}}=32 /\left(16+d_{\mathrm{g}}\right)$

$f_{\mathrm{yd}}$ - yield strength of the reinforcement, $f_{\mathrm{yd}}=f_{\mathrm{yk}} / \gamma_{\mathrm{s}}$

$r_{\mathrm{s}}$ - distance between the column axis and sections with zero radial bending moments, $r_{\mathrm{s}}=1.18 \mathrm{~m}$

\section{Closed form CSCT model - CF CSCT}

The model is based on the CSCT. In order to simplify the design of flat slabs for designers, the basic formula (5) has been changed and expressed in a closed form (9). Muttoni and Ruiz (2017) assumed the yielding of the main reinforcement in (7). The failure criterion (6) has been replaced by a power-law criterion. The maximum punching capacity is determined by the $\eta_{\text {sys }}$ factor, see Table 1 , which is applied with the punching resistance without any shear reinforcement $V_{\text {Rd,c }}$, see Formula (8).

$$
\begin{gathered}
V_{\mathrm{Rd}, \text { max }}=\eta_{\mathrm{sys}} V_{\mathrm{Rd}, \mathrm{c}} \\
V_{\mathrm{Rd}, \mathrm{c}}=\frac{k_{\mathrm{b}}}{\gamma_{\mathrm{C}}}\left(100 * \rho f_{\mathrm{ck}} \frac{d_{\mathrm{dg}}}{a_{\mathrm{v}}}\right)^{1 / 3} b_{0} d_{\mathrm{v}} \leq 0.6 * \frac{\sqrt{f_{\mathrm{ck}}}}{\gamma_{\mathrm{C}}} b_{0} d_{\mathrm{v}} \\
k_{\mathrm{b}}=\sqrt{8 * \mu \frac{d}{b_{0}}}
\end{gathered}
$$

Where:

$d_{\mathrm{dg}}$ is $32[\mathrm{~mm}]$ for concrete of a normal weight

$a_{\mathrm{v}}$ - shear span $a_{\mathrm{v}}=1.18 \mathrm{~m}$

$\mu$-parameter accounting for the shear force and bending moment in a shear region, for an internal column without any unbalanced moment $\mu=8$.

\subsection{Comparison of the assessed and experimental results}

The assessments of the punching resistance were carried out with partial safety factors $\gamma_{\mathrm{C}}$ and $\gamma_{\mathrm{S}}$, which are equal to 1 . The measured mean values of the cylinder compressive strength of the concrete $f_{\mathrm{cm}}$ were used instead of $f_{\mathrm{ck}}$ and $f_{\mathrm{cd}}$ in the relevant formulae. For an evaluation of $m_{\mathrm{Rd}}$, the mean value of yield strength $f_{\mathrm{ym}}$ of the reinforcing steel was used, see Table 2. The maximum aggregate size used for the concrete mix was $16 \mathrm{~mm}$; therefore, $k_{\mathrm{dg}}=1.0$.

\section{Specimens without any shear reinforcement}

A comparison of the test results with the assessed punching resistances is shown in Table 3 . The results obtained indicate very good agreement between the measured and predicted values in the case of specimen S1-2. In the case of specimen S2-2, it seems that the failure was a bit premature. The reason could be the imperfect axis-symmetric conditions during the test. 
Tab. 3 Comparison of the test results with the assessed punching resistances

\begin{tabular}{|c|c|c|c|c|c|c|c|c|c|c|}
\hline \multirow{3}{*}{ Spec. } & \multirow[b]{2}{*}{$f_{\mathrm{cm}}$} & \multirow[b]{2}{*}{$V_{\mathrm{R}, \text { test }}$} & \multicolumn{2}{|c|}{ EC2 (2004) } & \multicolumn{2}{|c|}{ ETA13/0151 } & \multicolumn{2}{|c|}{ MC 2010} & \multicolumn{2}{|c|}{ CF CSCT } \\
\hline & & & $V_{\mathrm{Rd}, \mathrm{c}}$ & Test/Model & $V_{\mathrm{Rd}, \mathrm{c}}$ & $\mathrm{T} / \mathrm{M}$ & $V_{\mathrm{Rd}, \mathrm{c}}$ & $\mathrm{T} / \mathrm{M}$ & $V_{\mathrm{Rd}, \mathrm{c}}$ & $\mathrm{T} / \mathrm{M}$ \\
\hline & {$[\mathrm{MPa}]$} & {$[\mathrm{kN}]$} & {$[\mathrm{kN}]$} & - & {$[\mathrm{kN}]$} & - & {$[\mathrm{kN}]$} & - & {$[\mathrm{kN}]$} & - \\
\hline $\mathrm{S} 1-2$ & 41.0 & 903 & 888 & 1.017 & 784 & 1.152 & 747 & 1.208 & 917 & 0.984 \\
\hline S2-2 & 28.1 & 690 & 783 & 0.881 & 691 & 0.998 & 648 & 1.065 & 759 & 0.909 \\
\hline
\end{tabular}

Tab. 4 Factors $k_{\max }$ assessed by the test results

\begin{tabular}{|c|c|c|c|c|c|c|c|c|c|c|}
\hline \multirow{3}{*}{ Spec. } & \multirow[b]{2}{*}{$f_{\mathrm{cm}}$} & \multirow[b]{2}{*}{$V_{\mathrm{R}, \text { test }}$} & \multicolumn{2}{|c|}{ EC2 (2004) } & \multicolumn{2}{|c|}{ ETA13/0151 } & \multicolumn{2}{|c|}{ MC 2010} & \multicolumn{2}{|c|}{ CF CSCT } \\
\hline & & & $V_{\mathrm{Rd}, \mathrm{c}}$ & $k_{\max }$ & $V_{\mathrm{Rd}, \mathrm{c}}$ & $k_{\max }$ & $V_{\mathrm{Rd}, \mathrm{c}}$ & $k_{\mathrm{sys}}$ & $V_{\mathrm{Rd}, \mathrm{c}}$ & $\eta_{s y s}$ \\
\hline & {$[\mathrm{MPa}]$} & {$[\mathrm{kN}]$} & {$[\mathrm{kN}]$} & - & {$[\mathrm{kN}]$} & - & {$[\mathrm{kN}]$} & - & {$[\mathrm{kN}]$} & - \\
\hline S1-1 & 38.2 & 1520 & 867 & 1.75 & 765 & 1.99 & 478 & 3.18 & 885 & 1.72 \\
\hline S2-1 & 28.1 & 1250 & 783 & 1.60 & 691 & 1.81 & 472 & 2.65 & 759 & 1.65 \\
\hline \multicolumn{4}{|c|}{ Values introduced in the standards } & 1.50 & & 1.96 & & 2.80 & & 1.80 \\
\hline
\end{tabular}

Tab. 5 Maximum punching resistance based on direct control of the concrete struts

\begin{tabular}{|c|c|c|c|c|c|c|c|c|c|c|}
\hline \multirow{3}{*}{ Spec. } & & & \multicolumn{3}{|c|}{ EC2 (2004) } & \multicolumn{3}{|c|}{ EC2 (2004) } & \multicolumn{2}{|c|}{ MC2010/CF CSCT } \\
\hline & $f_{\mathrm{cm}}$ & $V_{\mathrm{R}, \text { test }}$ & $v$ & $V_{\mathrm{Rd} \text { max }}$ & $V_{\mathrm{R}, \text { test }} / V_{\mathrm{Rd} \text {,max }}$ & $v$ & $V_{\mathrm{Rd}, \max }$ & $V_{\mathrm{R}, \text { test }} / V_{\mathrm{Rd}, \text { max }}$ & $V_{\mathrm{Rd} \text { max }}$ & $V_{\mathrm{R}, \text { test }} / V_{\mathrm{Rd}, \text { max }}$ \\
\hline & {$[\mathrm{MPa}]$} & {$[\mathrm{kN}]$} & & {$[\mathrm{kN}]$} & - & & {$[\mathrm{kN}]$} & - & {$[\mathrm{kN}]$} & - \\
\hline S1-1 & 38.2 & 1520 & 0.508 & 1098 & 1.384 & 0.6 & 1296 & 1.173 & 1476 & 1.029 \\
\hline S2-1 & 28.1 & 1250 & 0.533 & 846 & 1.477 & 0.6 & 953 & 1.311 & 1266 & 0.987 \\
\hline
\end{tabular}

\section{Specimens with a shear reinforcement}

The governing mode of the failure of the slabs with a shear reinforcement was the crushing of the struts, which is clearly visible in the saw-cut section of the S1-1 specimen. The failure zone is located very close to the column's periphery; therefore, the failure loads can be regarded as the maximum punching capacity of the test specimens. Table 4 shows the values of $k_{\max }$ that were obtained as the ratio of the failure load and assessed punching capacity $V_{\mathrm{Rd}, \mathrm{c}}$. In the case of MC2010, different values of $V_{\text {Rd,c }}$ from the values in Table 3 followed from the calculation of $\psi$ with the failure load of the specimens with shear reinforcement. Only in the case of EC2 (2004), were the $k_{\max }$ factors greater than the values introduced in the standard for both specimens. In the case of the ETA and MC2010 models, specimen S2-1 provided a lower value, and in the case of the CF CSCT (2017) model, neither slab reached the value of $\eta_{s y s}$ introduced in the standard.

Many national annexes to EN1992-1-1 permit flat slabs reinforced by double-headed studs to use higher values of $k_{\max }$. This is acceptable only if there is a further criterion for the limiting of the maximum punching resistance applied. This criterion is based on the direct control of the punching capacity using formula (1). The CF CSCT model has a similar problem, where a second limit on the maximum punching capacity should be imposed. The recommended limit can be taken from the Model Code 2010, see formula (11). The maximum punching resistances evaluated by formulas (1) and (11) are in Table 5.

$$
V_{\mathrm{Rd}, \text { max }}=\frac{\sqrt{f_{\mathrm{ck}}}}{\gamma_{\mathrm{C}}} b_{0} d_{\mathrm{v}}
$$

In the case of EC2 (2004), two values of $V_{\text {Rd,max }}$ are introduced. The first are values assessed using factor $v$, which was determined based on the actual strength of the concrete. Since the results obtained are very conservative, a second value of $v$ equal to 0.6 was applied. This value is applicable if the shear reinforcement is not being yield- ed. The maximum punching capacities obtained provide a quite good prediction of the maximum punching capacity for cases where the crushing of the struts is the governing mode of the failure.

The $k_{\max }$ values obtained only from the experimental results are in Table 6. Since the concrete strengths of the S1-1 and S1-2 specimens were different, the punching capacity without any shear reinforcement has been adjusted by the factor introduced in the last row of the table.

Tab. 6 Maximum punching resistances obtained from the tests

\begin{tabular}{|c|c|c|c|c|}
\hline \multirow{2}{*}{ Specim. } & $f_{\mathrm{cm}}$ & $V_{\mathrm{R}, \text { test }}$ & $V_{\mathrm{Rc}, \text { test }}$ & $k_{\max }$ \\
\cline { 2 - 5 } & {$[\mathrm{MPa}]$} & {$[\mathrm{kN}]$} & {$[\mathrm{kN}]$} & $V_{\mathrm{R}, \text { test }} / V_{\mathrm{Rc}, \text { test }}$ \\
\hline $\mathrm{S} 1-1$ & 38.2 & 1520 & $\left.881^{*}\right)$ & 1.725 \\
\hline $\mathrm{S} 2-1$ & 28.1 & 1250 & 690 & 1.811 \\
\hline
\end{tabular}

\section{CONCLUSIONS}

Two methods for assessing the maximum punching resistance of flat slabs with a shear reinforcement are currently used. The first method is based on the punching capacity without any shear reinforcement $V_{\mathrm{Rdc}}$ multiplied by factor $k_{\max }$. The second method is based on the direct verification of the strut capacity at the column's periphery. Since the control of the strut capacity is only used in the current EC2 model and indirectly in the MC2010 and CF CSCT models, the possible failure due to the crushing of the struts was experimentally tested. Two flat slab specimens were over-reinforced by a shear reinforcement in such a way that the crushing of the struts preceded other forms of punching failures. From the test results and the theoretical analysis, the following conclusions can be drawn. 
- The maximum punching capacities obtained from the tests were $1520 \mathrm{kN}$ and $1250 \mathrm{kN}$, while the punching resistances without any shear reinforcement were $881 \mathrm{kN}$ and $690 \mathrm{kN}$ and thus experimentally evaluated $k_{\max }$ factors reached values of 1.725 and 1.80 respectively.

- The $k_{\max }$ factor recommended for the current EC2 model 1.5 is on the safe side for both specimens and even allows for the removal of the strut capacity control in the case of punching, see the German NA. However, in the case of flat slabs, where the crushing of the concrete struts is not the governing mode of punching failure, the model provides conservative solutions, e.g., it requires thicker slabs or a higher amount of bending reinforcement.

- The higher values of $k_{\max }$ factor $>1.6$ in the case of flat slabs with a transverse reinforcement from double-headed studs are acceptable, but only with direct control of the strut's capacity.

- In the case of the ETA 13/0151 model, the value of the $k_{\text {max }}$ factor 1.96 is very high, if we consider that the assessment of the strut capacity is not included in the model. The adjustment of the $V_{\text {Rd.c }}$ by the length of the column's periphery would improve the current situation but seems insufficient. The $k_{\max }$ factors evaluated using the test results were 1.99 and 1.81 .
- In the case of mechanical models based on the CSCT theory, the factors $k_{\text {sys }}$ reached values of 3.18 and 2.65, while the recommended value is 2.8 . Factor $\eta_{\text {sys }}$ reached values of 1.72 and 1.65 respectively. Both values are lower than the recommended value of 1.8. Thanks to the second limit, see formula (11), both models can be regarded as safe from the point of view of the maximum punching capacity.

\section{Acknowledgements}

This work was supported by the Scientific Grant Agency of the Ministry of Education, Science, Research and Sport of the Slovak Republic and the Slovak Academy of Sciences No. 1/0810/16 and by the Slovak Research and Development Agency under Contract No. APVV-15-0658.

\section{REFERENCES}

Einpaul, J., Bujnak, J., Ruiz, F. M., and Muttoni, A. (2016) Study on Influence of Column Size and Slab Slenderness on Punching Strength, In: ACI Structural Journal, Jan.-Feb. 2016, pp.135-145

European Technical Approval ETA 13/0151, Deutsches Institute fur Bautechnik

Muttoni A., Schwartz, J. (1991) Behavior of Beams and Punching in Slabs without Shear Reinforcement, IABSE Colloquium, Vol. 62, Zurich, Switzerland, 1991, pp. 703-708

Muttoni A., Ruiz, F. M. (2008) Shear strength of members without transverse reinforcement as function of critical shear crack width, ACI Structural Journal, V. 105, No. 2, 2008, pp. 163-172

Muttoni, A., Bujnak, J. (2013) "Performance of slabs reinforced by Peikko PSB studs demonstrated by full scale tests and validated by ETA approval starting April 2013", Concrete connection 01/2013, customer magazine of Peikko Group.
Muttoni A. and Ruiz M. F., (2017), "The Critical Shear Crack Theory for punching design: From a mechanical model to closedform design expressions ". In: ACI-fib International Symposium: Punching shear of structural concrete slabs, Honoring Neil M. Hawkins: ACI-fib symposium proceedings, ACI SP-315. Oct. 2016, Phila., pp. 237-252.

PSB Reinforcement against punching failure of slabs, Technical Manual, $06 / 2013$

Ruiz F.,M., Muttoni A. (2009) Applications of Critical Shear Crack Theory to Punching of Reinforced Concrete Slabs with Transverse Reinforcement, In: ACI Structural Journal, V. 106, No. 4, July-Aug. 2009, pp.485-494

Zsutty, T. (1968) Beam shear strength prediction by analysis of existing data. ACI Journal 65(11): pp. 943-951. 